\title{
Educational Resilience from Parental Perspective
}

\author{
Hannu Räty ${ }^{1}$, Kati Kasanen ${ }^{1} \&$ Riitta Rautiainen ${ }^{1}$ \\ ${ }^{1}$ Department of Education and Psychology, University of Eastern Finland, Finland \\ Correspondence: Hannu Räty, Department of Education and Psychology, University of Eastern Finland, Finland. \\ E-mail: hannu.raty@uef.fi
}

Received: November 27, 2013

doi:10.5539/jedp.v4n1p1
Accepted: December 9, $2013 \quad$ Online Published: December 24, 2013

URL: http://dx.doi.org/10.5539/jedp.v4n1p1

\begin{abstract}
In this study we explored the contribution of parents' perceptions of their child's resilience to their assessments of the child's abilities and academic proficiencies. We examined whether parents' perceptions of their child's resilience would predict, independently of the child's assessed competencies, their appraisals of the child's respective competencies across a four-year time span. A group of academically and vocationally educated parents $(\mathrm{N}=326)$ evaluated their child's resiliencies (education-related, persistence, and confidence) when the child was in the fifth grade. The parents also assessed their child's competencies in various abilities and school subjects. They then repeated these assessments once the child had entered the ninth grade, i.e., at the end of his/her compulsory education. Linear regression analyses indicated that the parents' perceptions, especially those of their child's educational resilience, did have significant effects on their assessments of the child's verbal-cognitive competencies. In addition, the results suggested that perceptions of a child's resiliencies might be more pertinent for academically educated than for vocationally educated parents. Accordingly, even though parental assessments of their child's future competencies are closely associated with the respective assessments of his/her current competencies, the perceptions of the child's educational resilience may function as a separate basis for parents' appraisals of their child's competencies.
\end{abstract}

Keywords: educational resilience, parental perception, perceived competencies, social differences

\section{Introduction}

While there are different definitions of childhood resilience, it is generally thought to represent an important psychological resource for coping. Although childhood resilience has also been addressed from the educational point of view, there are few studies in existence on how parents perceive their child in terms of resilience and how these perceptions pertain to their assessments of the child's competencies. In this study, we define the concept of educational resilience as a collection of beliefs indicating parental confidence in the child's educational potential, based on trust in the child's relatively stable and general internal capacity for learning. Our longitudinal study set out to investigate whether parents' perceptions of their child's resilience would predict their appraisals of the child's competencies across a four-year time span.

Besides the psychological point of view, childhood resilience has also been addressed from the educational perspective. Jew, Green, and Kroger (1999), for example, concluded that resilient students are likely to have better academic skills, a higher self-perceived competence in scholastics, and more coping skills than their less resilient peers. Borman and Overman (2004) found that those children who had resilient outcomes in mathematics were more strongly involved in academic activities and had a more positive attitude towards school than children with non-resilient outcomes. Moreover, resilient children seem to perceive their learning environment more positively than non-resilient children, which may promote the academic accomplishments of resilient children (Padron, Waxman, \& Huang, 1999). Thus, achievement at school is often regarded as an indicator of resilience (Carr \& Claxton, 2002).

Parents' views of their children's development in terms of their capacities and inclinations are of significance (e.g., Goodnow \& Collins, 1990). There is convincing research-based evidence that the level of parents' belief in their child's abilities is related to the child's views of his/her own competencies (e.g., Bouffard \& Hill, 2005), which further influences their learning outcomes (e.g., Galper, Wigfield, \& Seefeld, 1997; Wigfield \& Eccles, 2000). Accordingly, children's academic achievements (e.g., in the form of feedback from the school) do not 
only influence parents' perceptions but parents' (prior) perceptions also influence their child's competence beliefs and concrete achievements. Similarly, we may assume that parental perceptions of their child's educational resilience as a generalized belief contributes to parental perceptions and explanations of their child's academic success and failure. As far as we know, there are few studies in existence concerning how parents perceive their child in terms of resilience and how these perceptions relate to their appraisals of the child's abilities and success at school (cf. Duran, 1999; Wyman et al., 1999).

In studying the relationship between parental perceptions of their child's resilience and those of the child's competencies, it is advantageous to consider contextual and social factors (e.g., Howard, Dryden, \& Johnson, 1999). For instance, parents are not just parents but also mothers and fathers of boys or girls, and they have different educational backgrounds. These positions are also reflected in parents' attributions. In line with our culturally prevailing notion of intelligence, for example, parents expect boys to surpass girls in the cognitive domain, whereas girls are expected to outdo boys in the verbal-social domains (Tiedemann, 2000).

As for the parents' education, research has indicated that all across the child's compulsory school years, highly educated parents tend to see their child's verbal-cognitive competencies as higher than less educated parents see similar competencies in their child (Räty \& Kasanen, 2013). Social differences can also be identified in parents' explanations of their child's successes and failures at school. When asked to indicate their child's strongest subjects, academically educated parents are likely to explain their child's success in terms of talent more often than less educated parents do (Räty, Kasanen, \& Kärkkäinen, 2006; Rytkönen, Nurmi, \& Aunola, 2005). It would also seem that parents who give talent-based explanations or combined talent-and-effort reasons for their child's success have a significantly higher opinion of their child's mathematical (Räty \& Kärkkäinen, 2011) and verbal (Räty, 2010) proficiency all through the child's compulsory school years than those parents who give solely effort-based explanations for their child's success. For their child's success in the mother tongue, too, academically educated parents are inclined to give talent-based explanations more often than vocationally educated parents. It seems, then, that from the start, parental attribution and explanation patterns represent important modes of interpretation, which presumably form a consequential part of parental faith in the child's academic proficiencies, particularly among highly educated parents.

\subsection{Constructing a New Method of Measuring Resilience}

Given that educational resilience has not often been investigated in research, we set out in a previous study to construct a psychometrically useful scale to measure parents' views of not only their child's psychological resilience, but also of their child's educational resilience (Kärkkäinen, Räty, \& Kasanen, 2009). Based mainly on research into parental notions of intelligence, we defined the concept of educational resilience as parental confidence in the child's educability or educational potential, based on confidence in the child's relatively stable and general internal capacity for learning (Mugny \& Carugati, 1989). This belief also contains a conviction regarding the child's educational prospects, even when the child faces difficulties (Lareau, 1989). Thus, the definition stands for a generalized certainty of a child's personal potential, which even comes close to essentialist thinking (Wagner, Holtz, \& Kashima, 2009). We were interested in discovering whether the opinions reflecting these notions would form an independent construct in relation to psychological forms of resilience.

We collected a set of statements concerning educational resilience and other types of resilience, derived from a revision of the scale originally developed by Wagnild and Young (1993). This particular instrument, the Resiliency Scale (RS), measures two dimensions: personal competence and acceptance of self and life (e.g., Humphreys, 2003). Even though the RS was not originally developed for exploring parental perceptions of children's resilience, it functioned quite well with our participants, who formed a nationally representative sample of academically and vocationally educated parents with a child in the fifth grade. In a factor analysis, we obtained three dimensions: the first one referred to the parents' faith in their child's academic achievement and in the child's potential for further success, which we labelled "educational resilience"; the second dimension matched the personal competence item of the RS, which we labelled "persistence"; and the third dimension concurred with the RS item for acceptance of self and life, which we labelled "confidence".

The factor-analytically derived mean scales had satisfactory reliability coefficients. Furthermore, it was the child's perceived educational resilience that was associated with parental appraisals of the child's problem-solving abilities, learning motivation, and achievement in verbal-cognitive subjects. These connections indicated that parental perceptions of the child's educational resilience pertained to the child's academic competencies, suggesting that the rating scale had concurrent validity. The close connection between perceptions of resilience and assessments of abilities and proficiencies implies that these views tend to form an interrelated 
pattern of parental competence beliefs. Still, an important question remained open: whether parental perceptions of their child's educational resilience would also have an independent effect on parental perceptions of their child's proficiencies and abilities. This was the question we tried to answer in the present study.

\subsection{The Present Study}

The findings cited above were obtained in a longitudinal study. The same parents were asked to assess their child's competencies in the same abilities and school subjects four years later, when the child had entered the last year of his/her compulsory education. The follow-up design made it possible, then, to examine whether the parents' perceptions of their child's resiliencies measured during his/her fifth grade would have an independent predictive power on their assessments of the child's abilities and academic proficiencies during his/her ninth grade.

Moving on to junior high school (grades 7-9) is an interesting period for exploring the role of parental perceptions of their child's resiliencies, given that the move changes children's school life in numerous ways, including an increase in both academic requirements and explicitly normative evaluations (Stipek \& MacIver, 1989). These changes are probably connected with our findings that the parents' ratings of their child's academic proficiencies tended to stabilize or even decrease as the child entered junior high school (Räty \& Kasanen, 2013). We expected the parental ratings of their child's abilities and academic proficiencies as measured during the child's fifth grade to be the strongest predictors of the respective ratings conducted four years later, at the end of the child's comprehensive schooling.

If parental perceptions of their child's educational resilience are to represent an interpretation of the child's generalized educational potential, we might expect these perceptions to also independently predict the parents' assessments of the child's future competencies when the influence of assessments of the child's current level of academic competencies and abilities is controlled for. Furthermore, on the basis of our previous findings, we also assumed that the parents' perceptions of their child's educational resilience would predict their assessments of the child's achievement in verbal-cognitive subjects (mathematics and Finnish) and in problem-solving skills, rather than that in practical subjects (handicrafts) and in non-cognitive (social and creative) abilities.

Apart from the perceived competencies and resiliencies, we included three additional position factors as independent variables. Gender is a relevant issue to consider, since girls do better than boys at school, which is also reflected in parental assessments of their child's academic competencies and educational resilience (Räty \& Kasanen, 2013). We included the child's gender in our study but formulated no specific hypotheses for this variable. In addition, the parent's gender was included in the analyses, for our previous study had suggested that mothers tend to have a higher opinion of their child's educational resilience and confidence than fathers. The parent's education is also an appropriate variable to consider, as parental appraisals of their child's academic competencies in the verbal-cognitive domain are strongly connected with the parent's education (Räty \& Kasanen, 2013). Given that the perception of resilience may relate to parental confidence in the child's educational potential, it was interesting to compare academically or vocationally parents in this regard, even though we held no specific expectations regarding this aspect.

\section{Method}

\subsection{Participants}

The present study is part of a larger research endeavour addressing the contribution of gender and parents' education to children's schooling. A questionnaire concerning parents' views of their child's forthcoming education was sent to a nationwide random sample of parents who were judged on the basis of their current occupation as either vocationally or academically educated and who had a seven-year-old child ready to start school in the coming autumn. Finnish children start their nine-year-long comprehensive education at the age of seven, after a year of non-school-like pre-school. The questionnaire was sent to individual parents (mothers and fathers). The response rate was $66 \%$, providing a total of 850 responses. Since not all of the respondents turned out to clearly represent one or the other of the two desired educational groups, we omitted, for the present set of studies, those who did not meet our criteria (i.e., parents with only secondary-level education and those with no post-primary education), ending up with two parent groups that were internally homogeneous in terms of their post-primary education: vocationally educated parents and academically educated parents, totalling 574 subjects. The vocationally educated parents had completed at least a one-year vocational course but usually a two- to three-year vocational training course, and the academically educated parents had completed at least a lower academic degree (e.g., BA) but usually a higher degree (e.g., MA). 
These parents were contacted again at the end of their child's first, third, fifth, seventh, and ninth school years; that is, when the child was 7-15 years of age. The response rates were $85 \%, 88 \%, 91 \%, 92 \%$, and $93 \%$, respectively. Mothers tended to respond more actively than fathers, and academically educated parents responded more actively than vocationally educated parents.

In the present (i.e., the last) follow-up group of parents $(N=326), 69 \%$ were mothers and $31 \%$ were fathers; these two gender groups did not differ in terms of their child's gender. The group contained $53 \%$ vocationally educated parents and $47 \%$ academically educated parents; these two educational groups did not differ in terms of their gender or their child's gender. Girls' parents made up $51 \%$ and boys' parents $49 \%$ of the group. The parents' average age was 47 years $(S D=5.29)$ at the end of the final phase of the follow-up study.

\subsection{Questionnaire}

Educational resilience - The scale contained the following five factor-analytically derived statements (Kärkkäinen, Räty, \& Kasanen, 2009): "My child is good at many subjects", "My child has a better than average natural ability to learn", "If my child gets a poorer mark than usual in an exam, s/he is likely to raise his/her achievement to the usual level the next time", "My child can handle many things at a time", and "My child has possibilities of developing in many directions". A mean scale was computed, and its reliability coefficient was .82 .

Persistence - This scale included seven factor-analytically established statements: "My child is determined", "When my child is in a difficult situation, s/he can usually find his/her way out of it", "When my child makes plans s/he follows through with them", "My child has enough energy to do what s/he has to do", "My child stays interested in things", "My child has self-discipline", and "My child feels proud that s/he has accomplished things". The reliability coefficient of this mean scale was .85 .

Confidence - The scale consisted of the following five factor-analytically derived statements: "My child usually takes things in her/his stride", "My child is friends with her/himself", "My child relies on her/himself", "My child usually finds something to laugh about", and "My child can usually look at a situation in a number of ways". The reliability coefficient of this mean scale was .76.

Success in school subjects - In one part of the questionnaire, the parents were asked to assess their child's competencies in different school subjects on a five-point scale anchored by "clearly below average" (1) and "clearly above average" (5). The subjects included in this study were mathematics, Finnish, and handicrafts.

Abilities - In another part of the questionnaire, the parents were asked to assess how well a set of short statements described their child on a five-point scale anchored by "very little" (1) and "very much" (5). The following factor-analytically derived abilities were measured, and corresponding mean scales were computed: problem-solving skills ("solves problems quickly", "is able to integrate different things", "understands things quickly", and "finds the gist of the matter easily"), social skills ("ready to help others", "takes others into consideration", "adaptive", and "friendly"), and creativity ("has a good imagination", "artistic", and "creative"). Measured during the child's fifth grade, the reliability coefficient of the scale for problem-solving skills was .91 while that for social skills was .85 and that for creativity was .78 .

A set of linear regression analyses with the forced-entry method was used to examine how the parent's gender (1 = father, 2 = mother $)$, the child's gender $(1=$ boy, $2=$ girl $)$, and the parents' perceptions of their child's educational resilience, persistence, and confidence, as measured during the child's fifth grade, predicted their assessments of their child's competencies in abilities and school subjects measured during the child's ninth grade. To control for the effect of parents' assessments of the child's competencies at the baseline, the competence assessments conducted during the child's fifth grade were included as an independent variable in each analysis. This enabled us to see their relative importance in relation to the effects of other independent variables. We carried out the analyses separately for the academically educated parents and the vocationally educated parents, as we were interested in seeing whether their patterns of relationships were similar or not.

Admittedly, the independent variables were related to one another. Correlations among the forms of resilience varied between .45 and .39 , and their correlations with the child's assessed abilities and proficiencies were .08 and .70 , respectively. Even though several correlations were statistically significant, the strength of these connections was only moderate at best, suggesting that the variables had sufficient independence. This interpretation was supported by the collinearity statistics, indicating that all linear regression analyses were suitable for the data, with the variance inflation factors (VIFs) being $<10$ and the tolerances $>0.1$. In addition, 
preliminary analyses showed that in only a couple of analyses were there a few outliers, that is, cases that had standardized residual values above 3.0 or below -3.0 .

\section{Results}

\subsection{Perceived Resilience and Assessed Success in School Subjects}

In predicting parents' assessments of their child's success in school subjects, all regression models were statistically significant and explained a fair share of the variance, ranging from $34 \%$ to $51 \%$ (Table 1).

As expected, it was the parental ratings of their child's proficiencies given during his/her fifth grade that predicted the respective ratings measured during the child's ninth grade the most strongly in every school subject, as measured by the strength of the standardized beta coefficients: the parents who had a high opinion of their child's proficiencies also tended to have a high opinion four years later, and vice versa.

Parents' perception of their child's educational resilience also had a significant effect on their ratings of the child's competence in Finnish undertaken four years later among the academically educated parents and the vocationally educated parents. As to mathematics, the parental perception of the child's educational resilience had a significant effect only among the academically educated parents, suggesting that the parents with a higher opinion of their child's educational resilience saw their child's mathematical proficiency during his/her ninth grade in a positive rather than negative light, whereas the parents with a lower opinion of the child's educational resilience saw their child's mathematical proficiency in a negative rather than positive light. In both educational groups, the perceived resiliencies were not significantly linked with the parental ratings of their child's competence in handicrafts. Additionally, at the end of the child's final school year, the vocationally educated parents of girls had a higher opinion of their child's proficiency in Finnish than the vocationally educated parents of boys.

\subsection{Perceived Resilience and Assessed Abilities}

In all ability domains, it was the parental ratings of their child's competencies measured during his/her fifth grade that predicted the respective ratings supplied during the child's ninth grade the most significantly: the parents who had a good opinion of their child's abilities during the fifth grade were likely to have a good opinion four years later, and vice versa.

Among the academically educated parents, the parents' perception of their child's educational resilience also had a significant effect on their ratings of their child's problem-solving skills. Even though a similar trend was also noted among the vocationally educated parents, it did not quite reach a statistically significant level $(p=.08)$. As to social skills, the parental perception of their child's confidence had a significant effect only among the academically educated parents: the parents who had a favourable opinion of their child's confidence during his/her fifth grade had a favourable rather than unfavourable opinion of the child's social skills as s/he entered his/her ninth grade, and vice versa. A similar tendency was noted among the academically educated parents in regard to perceived persistence, but it did not quite reach the conventional level of statistical significance ( $p$ $=.08$ ). In addition, the child's gender contributed to the ratings of competence in creativity among both educational groups, suggesting that the parents of girls rated their child's creativity higher than boys' parents did during their child's last school year.

To sum up, regardless of the child's assessed cognitive-verbal competencies, the parents' perceptions of their child's educational resilience contributed to the child's assessed competencies four years later: the parents with a high certainty of their child's resilience were likely to have a relative positive opinion of their child's competencies, while the parents with a low certainty in their child's resilience tended to have a relative negative opinion of their child's competencies. 
Table 1. Multiple regression analyses predicting parents' assessments of their child's competencies in school subjects and abilities

\begin{tabular}{|c|c|c|c|c|c|c|c|c|c|c|c|c|}
\hline \multirow{3}{*}{$\begin{array}{l}\text { Independent } \\
\text { variables }\end{array}$} & \multicolumn{2}{|c|}{ Mathematics } & \multicolumn{2}{|c|}{ Finnish } & \multicolumn{2}{|c|}{ Handicrafts } & \multicolumn{2}{|c|}{ Problem-solving } & \multicolumn{2}{|c|}{ Social skills } & \multicolumn{2}{|c|}{ Creativity } \\
\hline & $\begin{array}{l}\text { Academic } \\
\text { parents }\end{array}$ & $\begin{array}{l}\text { Vocational } \\
\text { parents }\end{array}$ & $\begin{array}{l}\text { Academic } \\
\text { parents }\end{array}$ & $\begin{array}{l}\text { Vocation } \\
\text { al parents }\end{array}$ & $\begin{array}{l}\text { Academic } \\
\text { parents }\end{array}$ & $\begin{array}{l}\text { Vocation } \\
\text { al parents }\end{array}$ & $\begin{array}{l}\text { Academic } \\
\text { parents }\end{array}$ & $\begin{array}{l}\text { Vocation } \\
\text { al parents }\end{array}$ & $\begin{array}{l}\text { Academic } \\
\text { parents }\end{array}$ & $\begin{array}{l}\text { Vocational } \\
\text { parents }\end{array}$ & $\begin{array}{l}\text { Academic } \\
\text { parents }\end{array}$ & $\begin{array}{l}\text { Vocation } \\
\text { al parents }\end{array}$ \\
\hline & Beta & Beta & Beta & Beta & Beta & Beta & Beta & Beta & Beta & Beta & Beta & Beta \\
\hline $\begin{array}{l}\text { Assessed } \\
\text { competence }\end{array}$ & $.50^{* * *}$ & $.57^{* * *}$ & $.33 * * *$ & $.44 * * *$ & $.62 * * *$ & $.65^{* * *}$ & $.52 * * *$ & $.61^{* * *}$ & $.43^{* * *}$ & $.63^{* * *}$ & $.64 * * *$ & $.62 * * *$ \\
\hline $\begin{array}{l}\text { Educational } \\
\text { resilience }\end{array}$ & $.27^{* *}$ & .05 & $.29 * *$ & $.22 *$ & -.02 & -.06 & $.27^{* *}$ & .15 & -.06 & .01 & .09 & .08 \\
\hline Persistence & .02 & -.02 & .10 & -.05 & .14 & .05 & .09 & -.10 & .17 & .05 & -.08 & .04 \\
\hline Confidence & .09 & .01 & -.08 & -.02 & -.13 & .00 & -.05 & .08 & $.18^{*}$ & .01 & -.07 & -.07 \\
\hline Child's & -.03 & .12 & .09 & $.19^{* *}$ & .06 & .08 & -.04 & .05 & .06 & .06 & $.17^{* *}$ & $.12^{*}$ \\
\hline gender & & & & & & & & & & & & \\
\hline $\begin{array}{l}\text { Parent's } \\
\text { gender }\end{array}$ & .00 & -.06 & -.04 & -.08 & -.05 & .00 & -.06 & -.02 & -.00 & -.01 & -.04 & -.04 \\
\hline$F$ & $25.72 * * *$ & $14.02^{* * *}$ & $16.63^{* * *}$ & $17.48^{* * *}$ & 20.47 & $20.48^{* * *}$ & $31.53^{* * *}$ & $26.60^{* * *}$ & $16.73^{* * *}$ & $23.35 * * *$ & $25.07 * * *$ & $25.98 * * *$ \\
\hline $\mathrm{R}$ square & .51 & .34 & .41 & .39 & .46 & .43 & .56 & .49 & .41 & .46 & .51 & .49 \\
\hline
\end{tabular}

$* \mathrm{p}<.05, * * \mathrm{p}<.01, * * * \mathrm{p}<.001$

\section{Discussion}

As expected, the parents' assessments of their child's prior academic competencies and abilities proved to be the most effective predictor of the respective assessments conducted four years later, once the child had reached the final year of his/her compulsory schooling. Evidently, parents' views of their child's relative level of achievement are quite crystallized by this time, as they have been validated many times over by feedback from the school received on an almost daily basis.

Even so, as also expected, the parents' perceptions of their child's resiliencies did have independent predictive effects on their assessments of the child's abilities and academic proficiencies. This effect pertained, as was presumed, to the assessments in the verbal-cognitive domain, that is, to mathematics and Finnish and problem-solving skills, but not to handicrafts and creativity. Moreover, in line with our expectations, it was the perceived educational resilience that exercised predictive power over the verbal-cognitive domain, and not the other forms of resilience, such as persistence and confidence. Overall, these findings seem to provide a measure of further validity to the scale aimed at measuring parents' perceptions of their child's educational resilience (Kärkkäinen, Räty, \& Kasanen, 2009).

We can conclude that even though parents' assessments of their child's current competencies are strongly linked with their respective future assessments, their perceptions of their child's educational resilience may well function as a separate source for parental appraisal of the child's academic proficiencies. This suggests the possibility that the perception of a child's past level of attainment, including setbacks, can be surmounted, providing that the parent has faith in his/her child's underlying potential (e.g., Gupta \& Nidhi Singhal, 2004). This finding is of significance, given that junior high school presents several challenges to pupils and parents. Confidence in the child's capabilities, even if lowered by difficulties met, may reflect the "inductive potential of essence" (Wagner et al., 2009); thus, the child's achievement is understood in accordance with its presumed essence and even if $\mathrm{s} / \mathrm{he}$ does not currently exhibit the expected characteristic, it is predicted to show up eventually. This implication is of educational significance, given that parents' confidence in their child's competencies contributes positively to the child's academic self-concept (Fredricks \& Eccles, 2002). Admittedly, our follow-up study was relatively short and lacked external criteria for the child's achievements; further research is therefore needed to confirm the present findings.

The child's gender had a few significant effects. For instance, at the end of the child's compulsory education, vocationally educated parents emphasized their daughters' proficiency in Finnish. This finding may partly 
account for our earlier finding that vocationally educated parents expect their daughters to be much more likely than their sons to enter high school (Räty \& Kasanen, 2010).

Our interest in comparing academically and vocationally educated parents derived from the research findings that highly educated parents may have more faith in their child's educability (i.e., quite steady potential) than less educated parents have. In this respect, we did find a few interesting education-associated differences. The first notable finding related particularly to mathematics and also to problem-solving skills: parental perceptions of the child's educational resilience had a significant effect only among the academically educated parents. Both of the domains mentioned stand for cognitive intelligence, which is generally considered to be the most valued type of intelligence (Mugny \& Carugati, 1989). Cognitive ability is particularly valued by highly educated parents, for whom it is an important part of social identity (Räty \& Kasanen, 2013). Accordingly, educational resilience seems to be understood among academically educated parents chiefly in terms of the child's underlying cognitive faculty.

The second noteworthy education-related difference was associated with social skills: the parental perceptions of their child's confidence and, suggestively, persistence, but not of educational resilience, had a significant effect only among the academically educated parents. We may speculate that academically educated parents view social skills not only in terms of cooperation and sociability but also with an emphasis on the assertive aspects of behaviour. Assertive skills, including self-confidence, independence, and determination, are valued in jobs that call for autonomous professional orientations and outlooks (Kohn, 1969; Weininger \& Lareau, 2009). It may well be that academically educated parents' attributions of confidence and persistence contain assessments of the extent to which their child matches their upcoming academic habitus.

To sum up, the education-related differences seem to suggest that perceived resilience tends to play a more active role among academically educated parents than among vocationally educated ones. Though academic parents are inclined to consistently attribute more verbal-cognitive competencies to their children than vocational parents do, they also seem to evaluate their children more intensely in terms of verbal-cognitive competencies, implying that these particular competencies are pertinent to them.

This conclusion is somewhat similar to our previous results, which showed that academically educated parents take their child's further academic education for granted as early as the child's pre-school stage (Räty \& Kasanen, 2010). Though their assessments of their child's verbal-cognitive proficiencies also contribute to these expectations, academically educated parents probably do not use information pertaining to current ability when appraising whether their child will be able to continue in upper secondary education; rather, they use such information for predicting how well the child will do in high school.

This study should be interpreted in the light of the following limitations. We did not have data on the children's academic performance evaluated by the school (e.g., teacher ratings or test results). Although parents seem to have quite an accurate view of their child's academic performance (e.g., Hughes, Wikeley, \& Nash, 1994), it would be interesting to scrutinize the accuracy of these views, particularly those cases in which there are discrepancies between parents' assessments and the external criteria. For instance, would parental perceptions of their child's resilience help us to understand the cases in which parents have a high opinion of their child's competencies despite external evaluations showing considerably lower values, perhaps because of the child's learning difficulties? Evidently, we need more studies of situations that involve thriving adversities (e.g., Morrison \& Cosden, 1997; Heilman, 2002). Another limitation is that our definition of the child's educational resilience was based mainly on parental belief in the child's general educational capacity and our questionnaire on educational resilience included only one explicit statement concerning the overcoming of failures.

If parents' perceptions of their child's educational resilience contribute to their views of the child's educability and, subsequently, affect the child's achievements, we need studies to explore the reciprocal relationships between parents' resilience perceptions and their child's views of him/herself as a learner over the course of his/her schooling. Especially when we are dealing with learning difficulties, it is important to consider the teachers' accounts as part of the dynamics of these situations (Haan \& Wissink, 2013). Research on the interactive processes involved in explaining a child's academic successes and failures would also throw light on changes in parental perceptions of resilience.

Taken together, both our previous and present studies suggested that parental perceptions of educational resilience are not only linked with parental perceptions of their child's capabilities, but also form an independent and potentially consequential facet in parents' views of their child's schooling. Perceived resilience is a key part of parental trust in their child's educability and related prospects. 


\section{References}

Borman, G., \& Overman, L. (2004). Academic resilience in mathematics among poor and minority students. The Elementary School Journal, 104, 177-195. http://dx.doi.org/10.1086/499748

Bouffard, S., \& Hill, N. (2005). Maternal perceptions of competence and children's academic adjustment: Longitudinal relations across early elementary school. Social Psychology of Education, 8, 441-463. http://dx.doi.org/10.1007/s11218-005-1327-4

Carr, M., \& Claxton, G. (2002). Tracking the development of learning disposition. Assessment in Education, 9 , 9-37. http://dx.doi.org/10.1080/09695940220119148

Duran, D. (1999). A retrospective study of academic resilience in successful Latino students from a rural California community. Dissertation Abstract International Section A: Humanities and Social Sciences, 61, $1-\mathrm{A}$.

Fredricks, J., \& Eccles, J. (2002). Children's competence and value beliefs from childhood through adolescence. Developmental Psychology, 38, 519-533. http://dx.doi.org/10.1037/0012-1649.38.4.519

Galper, A., Wigfield, A., \& Seefeld, C. (1997). Head start parents' beliefs about their children's abilities, task values, and performance on different activities. Child Development, 68, 897-907. http://dx.doi.org/10.2307/1132040

Goodnow, J., \& Collins, A. (1990). Development according to parents. Hillsdale, NJ: Erlbaum.

Gupta, A., \& Nidhi Singhal, N. (2004). Positive perceptions in parents of children with disabilities. Asia-Pacific Disability Rehabilitation Journal, 15, 22-35.

Haan, M., \& Wissink, I. (2013). The interactive attribution of school success in multi-ethnic schools. European Journal of Psychology of Education, 28, 297-313. http://dx.doi.org/10.1007/s10212-012-0115-8

Heilman, T. (2002). Parents of children with disabilities: Resilience, coping, and failure of expectations. Journal of Developmental and Physical Disabilities, 14, 159-171. http://dx.doi.org/10.1023/A:1015219514621

Howard, S., Dryden, J., \& Johnson, B. (1999). Childhood resilience: Review and critique of literature. Oxford Review of Education, 25, 307-233. http://dx.doi.org/10.1080/030549899104008

Hughes, M., Wikeley, F., \& Nash, T. (1994). Parents and their children's schools. Oxford, UK: Blackwell.

Humphreys, J. (2003). Resilience in sheltered battered women. Issues in Mental Health Nursing, 24, 137-152. http://dx.doi.org/10.1080/01612840305293

Jew, C., Green, K., \& Kroger, J. (1999). Development and validation of a measure of resilience. Measurement and Evaluation in Counselling and Development, 32, 75-89.

Kärkkäinen, R., Räty, H., \& Kasanen, K. (2009). Parents' perceptions of their child's resilience and competencies. European Journal of Psychology of Education, 24, 405-419. $\mathrm{http}: / / \mathrm{dx}$.doi.org/10.1007/BF03174769

Kohn, M. (1969). Class and conformity: A study in values. Homewood, IL: The Dorsey Press.

Lareau, A. (1989). Home advantage: Social class and parental intervention in elementary school. London: Falmer Press.

Morrison, G., \& Cosden, M. (1997). Risk, resilience, and adjustment of individuals with learning disabilities. Learning Disability Quarterly, 20, 43-60. http://dx.doi.org/10.2307/1511092

Mugny, G., \& Carugati, F. (1989). Social representations of intelligence. Cambridge: Cambridge University Press.

Padron, Y., Waxman, H., \& Huang, S. L. (1999). Classroom behavior and learning environment differences between resilient and nonresilient elementary students. Journal of Education for Students Placed at Risk, 4, 65-82. http://dx.doi.org/10.1207/s15327671espr0401_5

Räty, H. (2010). Do parents' explanations of their child's verbal competence relate to their assessments of the child's competence in the mother tongue? JERO - Journal for Educational Research Online, 2, 87-97.

Räty, H., \& Kärkkäinen, R. (2011). Talent or effort? Parents' explanations of their child's mathematical performance in relation to mathematical competence. Social Behavior and Personality, 39, 691-700. http://dx.doi.org/10.2224/sbp.2011.39.5.691 
Räty, H., \& Kasanen, K. (2010). A seven-year follow-up study on parents' expectations of their child's further education. Journal of Applied Social Psychology, 40, 2711-2735. http://dx.doi.org/10.1111/j.1559-1816.2010.00677.x

Räty, H., \& Kasanen, K. (2013). Parents' perceptions of their child's academic competencies construe their educational reality: Findings from a 9-year longitudinal study. Journal of Applied Social Psychology, 43, 1110-1119. http://dx.doi.org/10.1111/jasp.12076

Räty, H., Kasanen, K., \& Kärkkäinen, R. (2006). School subjects as social categorisations. Social Psychology of Education, 9, 5-25. http://dx.doi.org/10.1007/s11218-005-2439-6

Rytkönen, K., Nurmi, J., \& Aunola, K. (2005). Parents' causal attributions concerning their children's school achievement: A longitudinal study. Merrill-Palmer Quarterly, 51, 494-522. http://dx.doi.org/10.1353/mpq.2005.0027

Stipek, D., \& MacIver, D. (1989). Developmental change in children's assessment of intellectual competence. Child Development, 60, 521-538. http://dx.doi.org/10.2307/1130719

Tiedemann, J. (2000). Parents' gender stereotypes and teachers' beliefs as predictors of children's concept of their mathematical ability in elementary school. Journal of Educational Psychology, 92, 144-151. http://dx.doi.org/10.1037/0022-0663.92.1.144

Wagner, W., Holtz, P., \& Kashima, Y. (2009). Construction and deconstruction of essence in representing social groups: Identity projects, stereotyping, and racism. Journal for the Theory of Social Behavior, 39, 363-386. http://dx.doi.org/10.1111/j.1468-5914.2009.00408.x

Wagnild, G., \& Young, H. (1993). Development and psychometric evaluation of the resilience scale. Journal of Nursing Measurement, 1, 165-178.

Weininger, E., \& Lareau, A. (2009). Paradoxical pathways: An ethnographic extension of Kohn's findings on class and childbearing. Journal of Marriage and Family, 71, 680-695. http://dx.doi.org/10.1111/j.1741-3737.2009.00626.x

Wigfield, A., \& Eccles, J. (2000). Expectancy-value theory of achievement motivation. Contemporary Educational Psychology, 25, 68-81. http://dx.doi.org/10.1006/ceps.1999.1015

Wyman, P., Coven, E., Work, W., Hoyt-Meyers, L., Magnus, K., \& Fagen, D. (1999). Caregiving and developmental factors differentiating young at risk urban children showing resilient versus stress-affected outcomes. Child Development, 70, 645-659. http://dx.doi.org/10.1111/1467-8624.00047

\section{Copyrights}

Copyright for this article is retained by the author(s), with first publication rights granted to the journal.

This is an open-access article distributed under the terms and conditions of the Creative Commons Attribution license (http://creativecommons.org/licenses/by/3.0/). 